\title{
Comparison of Sellers's Awareness to Environmental Hygiene of Market Bulak, Market Klender and Market Rawamangun, East Jakarta
}

\author{
Maulidya Hasana P., ${ }^{*}$ \\ ${ }^{1}$ Master Program of Environmental Science, School of Postgraduate Studies, Diponegoro University, Semarang-Indonesia
}

\begin{abstract}
This research is motivated by the difference of market hygiene condition, where the market hygiene level is influenced by the environment around the market. In general, markets located near densely populated housing tend to be overlooked, while markets near elite housing tend to be clean. This condition is also influenced by marketers' awareness of market hygiene. If the market is near the elite neighbourhood, the level of awareness of sellers on cleanliness will be high. If the market is located in a densely populated area, sellers generally do not pay attention to cleanliness. The purpose of this research is to know the sellers's awareness of environmental cleanliness of Market Bulak, Klender Market and Rawamangun Market. Respondents in this study are sellers and buyers who make transactions in these 3 markets. This type of research is descriptive analys is with the method of observation and interview to 10 sellers in each market. Seller hygiene awareness are poor.
\end{abstract}

\section{Introduction}

Healthy, clean and comfortable environment is everyone's dream in life. To achieve this is a very complex in making humans as the main actors who are truly aware of the meaning of clean, healthy life so as to create a clean, healthy and comfortable environment. It is a very complex to achieve in making someone as the main actors who are truly aware of the meaning of clean, healthy life so as to create a clean, healthy and comfortable environment. It needs to be instilled the importance of hygiene to members of the community so that they have an awareness to maintain the environment [1].

Healthy, clean and comfortable environment also expected to exist a market, as well as traditional market. The goods in traditional market usually household daily needs. Traditional markets are usually associated with a negative impression, namely dirty and less comfortable. If traditional market conditions are not change, it is not impossible later it will be abandoned by consumers. Later this possibility will be more clear considering the rapid growth of modern market especially in Jakarta. However, traditional markets have a natural competitive advantage that is not directly owned by modern markets. Strategic location, large sales area, complete diversity of goods, low prices, a bargaining system that demonstrates intimacy between sellers and buyers is an advantage possessed by traditional markets [2].

Creating a clean and healthy environment is a shared responsibility. Especially the people around the neighborhood. They have an important role in protecting the environment and creating a clean and healthy environment .Creating a clean and healthy environment in the market is a shared responsibility of all stakeholder. Each one of them have an important role in protecting the environment and creating a clean and healthy environment. The awareness and consciousness level of most of seller in traditional market on the maintenance of the environment is still lacking.

In Yulianto study said education determines how seller think and understand in the sorting of waste. Low educated seller does not understand how to sort waste properly because do not understand the benefits it generated after. The higher the education level of a person then the more high the way of thinking and understanding in sorting waste [3].

The availability of a dumpster and trash can prepared by the market management can trigger a person to dispose waste init place. In other case a lot of this trash is missing this is very burdensome to the market management. A good trash must be strong, not easy to leak or crack, easy to open and closed again, so that the smell of garbage is not smelled and invisible from the outside.

Researcher interested to compare the awareness and consciousness of seller to the cleanliness of the environment in three traditional markets, namely Bulak Market, Klender Market and Rawamangun Market in East Jakarta.

Bulak Market is located in Klender village, Duren Sawitsubdistrict. Owned by Privat Company. In front and back side of Bulak Market there is crowded densely populated housing and in the right sight are well-resettled settlements from middle-class society. At the left side of Bulak Market lies Citra Mall Klender with four stories building, and at forth story there is super market but less visitor come there. People prefer buy vegetables in Bulak Market which cheaper. The Bulak Market building is one-

\footnotetext{
*Corresponding author: lydia maulidya91@yahoo.com
} 
floor ward-shaped building and partitioned by the sellers themselves according to the area they rented. In this ward there are vegetables mix with fruit stall.

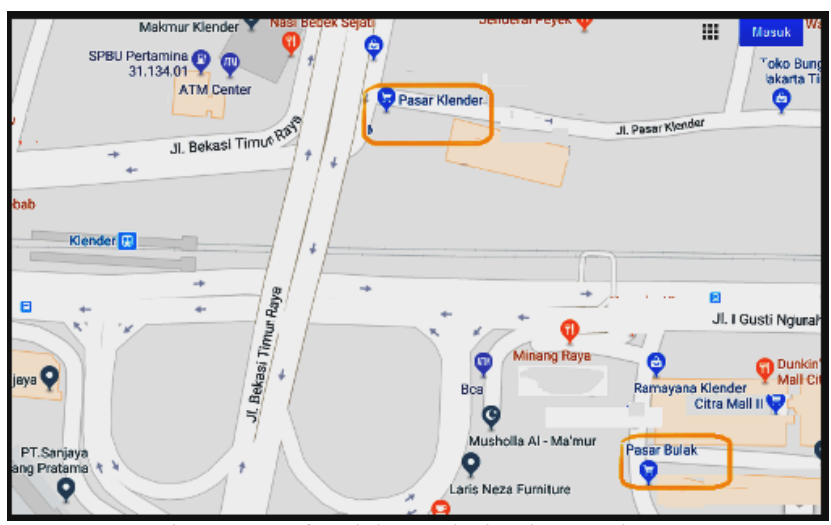

Fig. 1. Location Map of Bulak AndKlender Market

No live Poultry, but in separate building for fish sellers and dairy slices. Buying and selling activities in this market is different from most other traditional market, here last from afternoon until morning. There are no activities from eight o'clock in the morning until around four in the afternoon. Sellers in Bulak Market mostly sell their goods in larger quantity, because many of their costumer are vegetables retailer. Some of them sell vegetables, spices, herbs and fruits by their cart go around village. Catering entrepreneurs, and even sellers from Market Rawamangun who buy their goods here to sell in their stall.

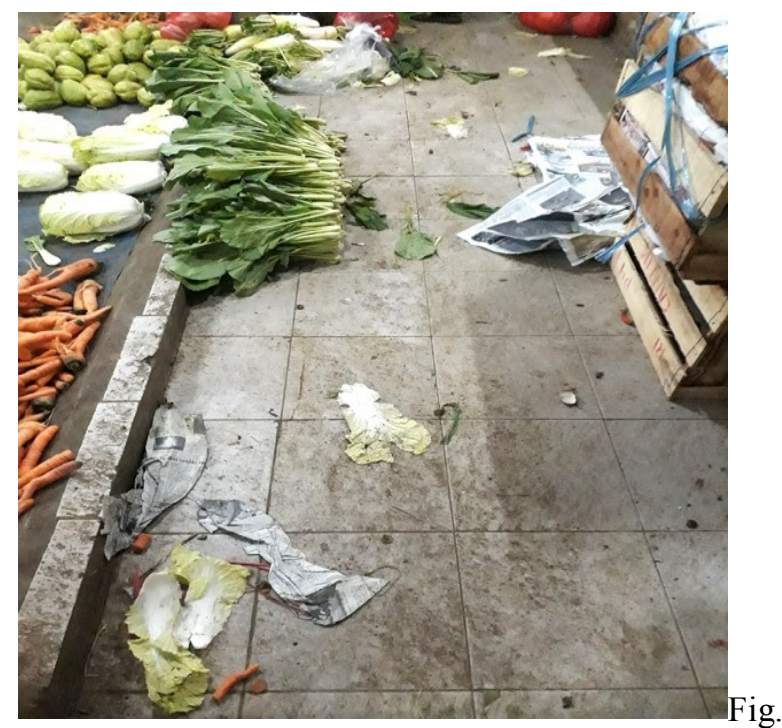

Fig. 2. Bulak Market Condition

Klender Market is located in Jatinegara Kaum Pulo village Gadung district Klender Market is by the side of a railway, and surrounded by a densely populated settlement that is generally inhabited by the weak economic community. This market is three-storey building and vegetable department is on the basement no fruit stall in this basement. There is meat stalls, dairy slices in addition to fish sellers, all located in the back part on one same flor. Living poultry sellers are on the back of the market building. Outside around market building there so many vegetables, fruit and also fish and meat seller as well as cooked food and cookies seller Consumers are generally housewives and cooked food maker. Quantity goods bought by customer are small. Fortunately this market easy to reach by customer who lives far away, because many public transportation passes and also near railway station. Many fruit seller of any kind of fruit especially banana sell their goods on footpath side by car way mostly in the afternoon until evening.

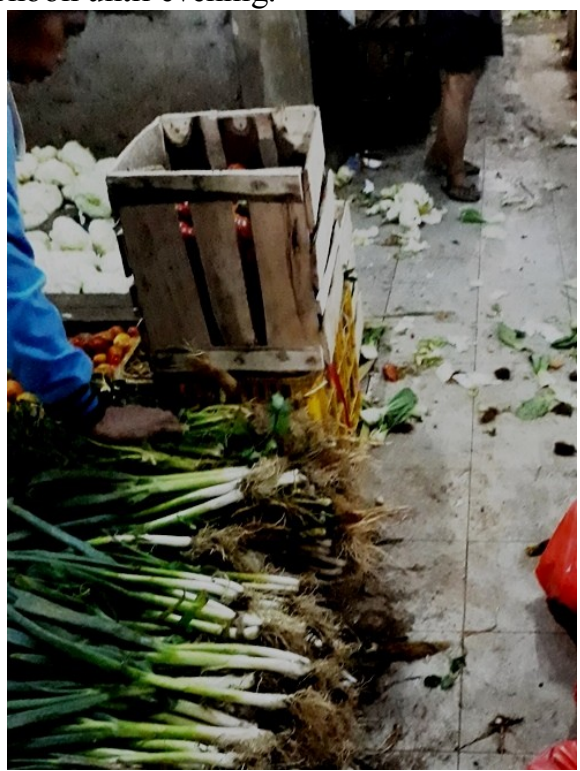

Fig. 3. Klender Market Condition

Rawamangun Market lies in a well-tended settlement of middle-class society. A three-story building with a vegetable department is on the ground floor. Vegetable area mix with fruit stall. The poultry sellers, meat and fish slices is located on the back of the basement stalls. Outside there are also life poultry sellers. Consumer Market Rawamangun generally housewives.

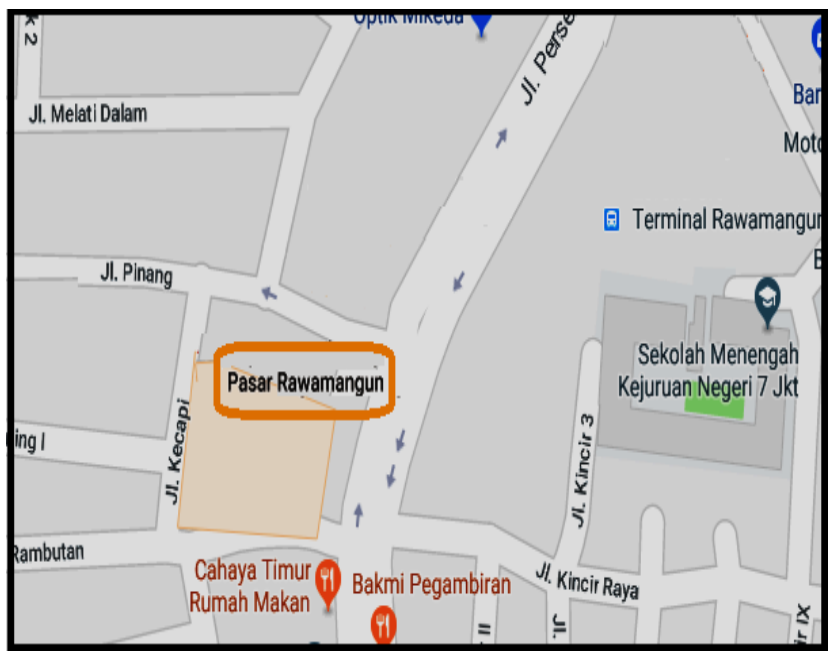

Fig. 4. Location Map of Rawamangun Market 
The part of the market observed is the vegetable part, because in this part the amount of waste is relatively large plus the behavior of marketers who are less concerned about the cleanliness of the environment. Waste of vegetables easily to decay. According to Anam [2] quickly decay or decomposition of garbage will more quickly create an unpleasant odor that leads to the impression of unhealthy, dirty and uncomfortable for the environment. Waste decay can lead to the appearance of pathogenic microorganisms and invite animal transporters or disease spreaders (vectors). The more vegetable waste the faster the environmental problems arise, the more uncomfortable the environment, this can not be separated from the seller's awareness of environmental cleanliness. Therefore, the waste must be managed properly, making the environment healthy, clean and add aesthetic value. Faridha (2001 in Hermawan Y) found a significant relationship between knowledge and seller behavior in managing environmental hygiene.

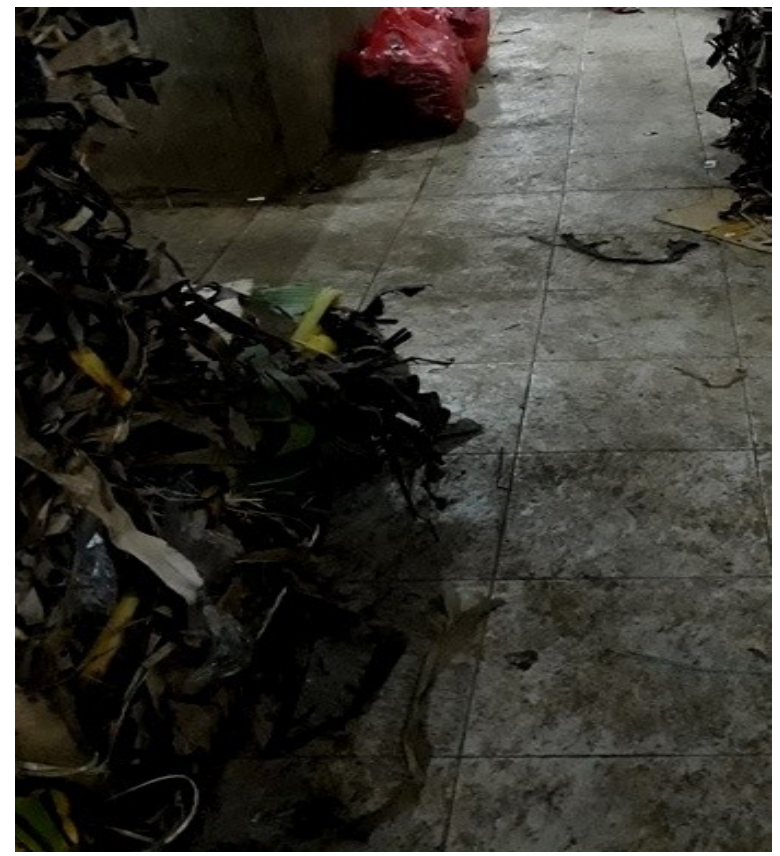

Fig. 5. Rawamangun Market Condition

The people live around the market affects the reason of consumers to the market, some consumers visit the market for reasons of near so that more economical for them, some because of the lower price, quality and completeness of vegetables, there is also a visit for convenience reasons. Middle class people are more selective in choosing quality (freshness) and convenience shopping, for them the price is the second consideration. This community is willing to come to a market that is located relatively far provided that there is a quality product and shopping convenience. For people who are classified as a weak economy are more concerned with product prices and ease of reaching the market, for example by walking.

\section{Research methode}

This type of research belongs to qualitative research. Qualitative research is research that is intended to understand the phenomenon of what is experienced by the subject of the researcher. The research was conducted in Bulak Market, Klender Market, and Rawamangun Market, East Jakarta. In order to obtain data and information relevant to the research problem, the data collection is done by determining the research informant. Selection of research informants conducted by purposive sampling, because by using purposive sampling technique the researcher can determine their own research informants based on research objectives, and also expected sample criteria obtained really in accordance with the research to be done. Informants in this study are 10 sellers and 10 buyers of each market. Sellers who are made in informants are people who are selling vegetables. Types of data in this study is primary data. Primary data is data that is directly collected in research. Sources of data in this study is the primary data obtained from interviews and observation,

\section{Research result and discussion}

Most of vegetables seller of Market Bulak are male which age around thirty to fifties. The goods quantity of each seller in Market Bulak is larger than Market Klender and Market Rawamangun seller. Vegetables are more varied in Market Bulak. Vegetable seller in Market Klender and Rawamangun seen older, male and female almost balance.

Based on researcher observation the hygiene of the three market environment is still not in accordance with expectations, even in the middle class environment. There are still many piles to the results of market activity in the market aisles. In market Bulak this is allegedly due to the low awareness, knowledge, education, habits, attitudes and experience of sellers about the importance of maintaining the cleanliness of the market environment. Lack of caring attitude of sellers to market hygiene problem will cause big impact to public health, and also negative impact to surrounding environment, hence need of cooperation among sellers in maintaining cleanliness of market environment.

The alley seen not too clean, in market Klender and market Rawamangun, there are some garbage heap. In market Bulak the alley clean lyness is worse, there are some alley covered by vegetables waste. Seller habits maintaining cleanliness still bad because of the many of them do not throw garbage in its place. This is due to the absence of responsibility the market management service in providing garbage space.

Writer interview result with seller show that awareness of them in maintaining hygiene of the market is still low due most mof them only collect waste of his wares, and put the garbage nearby their place, and some of them provide temporary dump like a sack.

Most of seller know that decaying garbage not good for health and aesthetic, according to most of them that cleanliness of alley not their responsibly, market management should pay attention to the hygiene of the 
market. According to them only few market visitor or buyer complaining dirty environment. Cleaning market alley is done twice a day, then the garbage put in certain place until dump truck from local government cleanliness agency.

Table 1. Characteristic of Markets

\begin{tabular}{|l|l|c|c|}
\hline Market & Location & $\begin{array}{c}\text { Market } \\
\text { hygiene }\end{array}$ & $\begin{array}{c}\text { Seller } \\
\text { hygiene } \\
\text { awareness }\end{array}$ \\
\hline Bulak & $\begin{array}{l}\text { Between } \\
\text { decent and } \\
\text { dense } \\
\text { settlements }\end{array}$ & Bad & Poor \\
\hline Klender & $\begin{array}{l}\text { Dense } \\
\text { settlements }\end{array}$ & Worse & Poor \\
\hline $\begin{array}{l}\text { Rawama } \\
\text { ngun }\end{array}$ & $\begin{array}{l}\text { Decent } \\
\text { settlements }\end{array}$ & Not too bad & Poor \\
\hline
\end{tabular}

Most seller tend to underestimate the issue of environmental hygiene conditions in which to trade and to attitudes toward health. The low level of awareness and consciousness of seller on environmental conditions can be seen from the attitude of most merchants that do not reflect the culture of clean and healthy living. The problem that has been the obstacle is caused by the seller in the market, because they do not show cooperative attitude and participation to help manage waste. Just as there are merchants who rarely sweep the merchandise so that it seems dirty. Although market management have tried to provide briefing and guidance about awareness and consciousness of the environment around their stall.

In general, most often buy vegetables in the market is housewives, the researchers interviewed the housewives who visited the market under study. They were asked why they chose the market they visited, how often they visited, what they opinion about the market condition, how it was compared to other traditional markets. The result that although they are not satisfied with market environment condition but they can tolerate. Some of the reason they choose the destination market is because it is close to their residence, the vegetable varied and more fresh also cheaper. According to them other traditional market condition almost same with destination market, except for newly renovated markets. Most of buyer are loyal buyer, it mean they always go to the market which they usually visit.

\section{Conclusion And Suggestion}

The environments cleanliness of the three market, almost same, even in middle-class neighborhoods. There are still many piles of market activity results in the market aisle. The seller awareness in the lack of caring attitude of sellers to the problem of market hygiene it will impact on public health, and also have negative impact on the surrounding environment, it is necessary cooperation between sellers in maintaining the hygiene of the market environment.

\section{References}

1. Y. Hermawan, H.O. Roesman, Jurnal Bumi Lestari Vol 8 No. 2 hal 186-192, 2008

2. C. Anam, Jurnal Sain danTeknologi Vol 7 No. 1, 2014

3. B. Yulianto, Jurnal Kesehatan Komunitas, Vol. 3 No, 2, 2016

4. S.Lestari, Perilaku Pedagang Dalam Membuang Sampah, FISIP UNILA, Skripsi, 2016

5. Sadino, J.A. Syahbana, Biro Penerbit Planologi Undip Volume 10 (2): 205-217 Juni 201

6. R. Sihotang, S. Afiddudin, Rahmanta, Jurnal Ekonom, Vol 17, No 4, Oktober 2014. 182 